\title{
Reflekterende team, en lærings- og veiledningsmetode i jordmorutdanningen
}

\author{
Anne-Lise Thoresen og Heidi Elvemo
}

I dette kapittelet ønsker vi å belyse hvordan systematisk refleksjon over praksiserfaringer bidrar til viktig kunnskapsdannelse i jordmorstudiet. Vi har utviklet reflekterende team (RT) som en undervisningsform der studentens praksiserfaringer danner grunnlag for personlig og profesjonell kunnskapsutvikling. Bevissthet om og trening i kommunikasjon og veiledning er sentrale tema i arbeidet. For å lykkes med dette er det vesentlig at studenten med egne ord får fortelle frem og dele det vesentlige i erfaringen, og undersøke hvordan hennes forståelse former hennes yrkespraksis. Studentenes refleksjonslogger etter hver arbeidsøkt er analysert med tanke på å forstå hvilken kompetanse RT som undervisningsform kan bidra til.

\section{Innledning}

I løpet av jordmorstudiet skal studentene få avansert kompetanse i kunnskapsgrunnlaget for profesjonell jordmorfaglig yrkesutøvelse og utvikle evne til å vurdere og handle i komplekse situasjoner på en etisk forsvarlig måte. I studieplanen til mastergradsutdanningen i jordmorfag (2019) ved UiT Norges arktiske universitet beskrives kommunikasjon og veiledning som gjennomgående og integrerte tema i hele studieforløpet. Gjennom ulike pedagogiske tilnærminger er målet å bidra til at studentene oppnår kommunikasjons- og refleksjonsferdigheter på et avansert nivå. Dette innebærer at utdanningen må utvikle læringsaktiviteter som er egnet til å 
få innsikt i og forståelse for sammenhengen mellom praktisk utøvelse av jordmorfag og teoretisk kunnskap, og reflektere et menneskesyn som er i tråd med International Confederation of Midwives' (ICM, 2014) etiske retningslinjer for jordmødre.

Reflekterende team (RT) som lærings- og veiledningsmetode representerer ett av flere kommunikasjons- og refleksjonsverktøy i jordmorutdanningen. I RT danner studentenes selvopplevde praksiserfaringer eller fortellinger utgangspunktet for veiledningen, og disse narrativene gjøres til gjenstand for kunnskapsutvikling gjennom dialogiske prosesser. Datamaterialet består av refleksjonslogger som jordmorstudentene har skrevet, og som forfatterne har analysert tematisk.

\section{Bakgrunn}

Jordmorutdanning og forberedelse til jordmoryrket er forankret i klinisk praksis der studentene får mulighet til læring gjennom veiledning og utøvelse av jordmoryrket. Forskningsbasert kunnskap og krav til profesjonell yrkesutøvelse er integrerte elementer i praksisutøvelsen (Sweet, Bass, Sidebotham, Fenwick \& Graham, 2019). Judith T. Fullerton, Joyce B. Thompson \& Peter Johnson (2013) fremmer betydningen av at studentene gis mulighet til å reflektere over egne praksiserfaringer. Læringsmetodene må ifølge Amanda G. Carter, Debra K. Creedy \& Mary Sidebotham (2017) gi studentene erfaring med kritisk tenkning og refleksjon, og hvordan denne innsikten kan overføres til klinisk praksis (klinisk resonnering). Jordmorstudentene må utvikle ferdigheter i kritisk refleksjon for å kunne gjøre profesjonelle vurderinger som er evidensbaserte, individualiserte og kvinnesentrerte. Dette innebærer at studentene må tilegne seg kunnskap om hvordan hun i møtet med den enkelte kvinne kan forstå nettopp denne kvinnens unike situasjon og tilpasse den jordmorfaglige omsorgen til henne (Gilkison, Giddings \& Smythe, 2016). En profesjonell jordmor må ha teoretisk, profesjonell og personlig kompetanse, gode kommunikasjonsferdigheter, moralske og etiske verdier samt emosjonell intelligens (Byrom \& Downe, 2010; Borrelli, 2014). Studentene må få innsikt i og erfaring med hvordan de selv kan integrere, kombinere og syntetisere ulike kunnskapsformer i egen praksis, slik at kunnskapen utgjør en helhet i møtet med den enkelte kvinne (Fullerton et al., 2013; ICM, 2013). Kunnskapsformene vil i tråd med Aristoteles (Aadland, 2018, s. 22) være knyttet til handling og omfatter 
techne, eller ferdighetskunnskap (knowing how), episteme - påstandskunnskap (knowing that) og fronesis som moralsk kunnskap (knowing what to do).

Steen Wackerhausen $(2009,2015)$ fremhever nødvendigheten av avansert refleksjon for å lære av egen praksis og erfaring slik at erfaringen rommer kritisk undersøkelse, noe som kan utgjøre en kilde til vekst og utvikling. Val Collington \& Sheila C. Hunt (2009) viser til at når refleksjon integreres i læringsaktivitetene, vil studentene fortsette med å være åpne for refleksjon som en nødvendig og integrert del av egen jordmorpraksis. Utvikling av refleksive ferdigheter harmoniserer ifølge Sue Macdonald (2017) med prinsipper for livslang læring i profesjonell yrkesutøvelse. Flere studier vektlegger studentenes mulighet for muntlig og skriftlig refleksjon, studentsentrert veiledning og kontinuitet som viktig for å utvikle profesjonell jordmorfaglig kompetanse (Bass, Fenwick \& Sidebotham, 2017; Embo \& Valcke, 2015).

Lene S. Nielsen, Per Munch \& Annegrete Nielsen (2019) fremmer betydningen av å utvikle refleksive læringsrom som bygger på studentenes egne erfaringer og narrativ, noe som gir studentene mulighet til å integrere profesjonskunnskap og personlig kunnskap. Parallelt med annen undervisning må studentene gis mulighet til å utvikle innsikt i betydningen av å tematisere og integrere teori og praksis i sin egen profesjonelle utvikling. Kritisk refleksjon over studentenes subjektive narrativ kan bidra til selvstendighet og profesjonell utvikling. Studentene vil i løpet av studiet oppdage jordmoryrkets kompleksitet og forventninger til profesjonell yrkesutøvelse, og lærernes oppgave i jordmorutdanningen er å tilrettelegge for ulike læringsmetoder, der studentene får mulighet til å utvikle seg til en profesjonell jordmor. RT er en av flere lærings- og veiledningsmetoder i jordmorutdanningen, og i dette kapittelet har forfatterne utviklet følgende forskningsspørsmål:

Hvordan kan veiledningsmetoden RT bidra til jordmorstudentenes læring og kunnskapsutvikling?

\section{Reflekterende team som veilednings- og læringsmetode i jordmorutdanningen}

RT utgjør en læringsmetode der studentene arbeider med refleksjon over erfaringer som studentene selv har opplevd i studieperiodene i klinisk jordmorpraksis. I denne læringskonteksten (RT) fokuseres det direkte på studenten og hennes fortelling, og studenten kan konsentrere seg om egne refleksjoner, tanker og 
følelser. Dette i motsetning til i kliniske praksisstudier, der oppmerksomheten til både jordmoren som veileder studenten, og studenten er rettet mot kvinnen og den kliniske situasjonen, der det alltid er kvinnens behov og interesser som skal prioriteres først. RT kan, for studenten, utgjøre et supplement og en mulighet for læring og profesjonell utvikling. I denne læringssituasjonen som RT utgjør, gis studenten mulighet til å oppdage og utfordre seg selv i en læringskontekst der hun selv er i fokus.

Gjennom forelesninger gis studentene en introduksjon til RT som veiledningsmetode. Siden bes studentene om å velge seg en hendelse/fortelling fra praksisperioden som de har tenkt mye på, eller på andre måter er opptatt av. Denne hendelsen skal de forberede skriftlig som en fortelling eller et veiledningsnotat, der de fokuserer på noe de vil ha hjelp til å diskutere eller finne ut av. Studentens fortelling er ikke kjent for teamet og mentor før veiledningen starter.

Studentene deles inn i grupper på seks til åtte personer. Gruppen utarbeider en gruppekontrakt, der taushetsplikt, respekt for hverandre og forpliktelse til gjensidig engasjement utgjør viktige deler av innholdet. Hver gruppe har en egen mentor som er lærer ved jordmorutdanningen, og som har et overordnet veiledningsansvar og følger studentene i alle gruppesamlingene. Studentene lager en plan der det avklares hvem som skal legge frem sin fortelling, og hvem som skal veilede. Alle studentene i gruppen skal få trening og erfaring med å være veileder, og alle skal motta veiledning (veisøker), slik at de får erfaring med begge rollene. Studentene som utgjør teamet, har som sin viktigste oppgave å diskutere saken som fortellingen omhandler, med respekt og forståelse både for den som gir, og den som får veiledning.

Rollene i RT fordeler seg slik:

- Veisøker - som muntlig og i dialog med veileder legger frem sin hendelse fra praksis

- Veileder - som ved dialog har ansvar for å hjelpe veisøker til å forstå hva erfaringen handler om, og hva som er viktig å belyse nærmere

- Teamet - som får i oppdrag å lytte, observere og notere, og ved invitasjon bidra til å speile det veisøker har sagt, og bringe inn nye perspektiver på saken

- Mentor - organiserer veiledningssekvensen og har ansvar for å ivareta og styre arbeidet i en anerkjennende og kunnskapsutviklende retning 
En sentral del av RT, slik metoden praktiseres i jordmorutdanningen, er den avsluttende dialogen, som inneholder en metarefleksjon der studentene og læreren sammenfatter kunnskapen som de i fellesskap har utviklet. I metarefleksjonen blir studentenes erfaringer med de ulike rollene i teamet diskutert. I tillegg løftes jordmorfaglige tema frem, samt hvordan studentene kan integrere kunnskapen i klinisk praksis. Læreren kan peke på vesentlige aspekter ved jordmorfaget som har kommet frem og blitt tydelig, i dialogen i RT. I dialogen og samarbeidet får studentene mulighet til å diskutere og utvikle en gjensidig forståelse for kunnskapen de i fellesskap har utviklet. Denne avsluttende dialogen kan fremstå som en kvalitetssikring av kunnskapsutviklingen og læringsprosessen (Lincoln \& Guba, 1985).

I tillegg til den muntlige dialogen i RT skrev studentene en refleksjonslogg umiddelbart etter hver veiledningsøkt, som en refleksjon over egen læring (Dewey, 2009). Loggene ble skrevet etter en mal der tre spørsmål inngikk: 1) Hva har du lært om kommunikasjon og veiledning? 2) Hvilken viktig innsikt/forstålse kom frem om det jordmorfaglige temaet som ble tatt opp? 3) Hvordan kan du bruke kunnskapen i andre situasjoner? En slik skriftlig bearbeiding av erfaringer kan beskrives som å være i dialog med seg selv, der studenten gjennom skriveprosessen kan bli bevisst egen læring og utvikling. Skrivearbeidet kan konstruere ny forståelse i en meningsskapende prosess og verbalisere studentens kunnskap (Dysthe, 2001; Nakielski, 2005).

\section{Annas fortelling}

Fortellingen til Anna (fiktivt navn) presenteres for å gi leseren innsikt i et eksempel fra RT og hvordan RT kan utspille seg i jordmorutdanningen. Annas fortelling er gjengitt, omarbeidet og anonymisert av forfatterne med tillatelse fra studenten.

«Det har jeg ikke tenkt på før!» utbryter jordmorstudenten. Vi sitter samlet $\mathrm{i}$ et grupperom på campus. Anna og en medstudent, som har rollen som veileder, sitter på hver sin stol plassert mot hverandre ved siden av et lite bord. Litt bortenfor sitter seks medstudenter rundt et annet bord. De utgjør studentens reflekterende team. Læreren sitter ved siden av teamet og har rollen som mentor. 
Dette er en fortelling fra min første praksis, der jeg kom til kort i kommunikasjon med kvinnen. Jeg fulgte en ung kvinne i fødsel. Kvinnen ønsket epiduralbedøvelse. Da tenkte jeg at jeg heller kunne motivere og støtte kvinnen til å mestre fødselen uten epiduralbedøvelse. Jeg har tidligere sett komplikasjoner i forbindelse med denne bedøvelsen, og informerte derfor om ulemper med dette. En av ulempene er at fødselen kan ta lang tid. I løpet av samtalen med kvinnen klarte jeg å påvirke henne til å ikke velge epidural. Hun hørte på meg. I ettertid har jeg tenkt over hvor mye makt jeg har som jordmorstudent i en slik situasjon. Vi snakket litt mer om fremgang i fødselen, og jeg lovet at fødselen skulle gå fint fremover. Men så skjedde det motsatte. Fødselen stoppet helt opp. Det ble vanskelig for meg å snakke med kvinnen, og jeg visste ikke hva jeg skulle si lenger. Jeg mistet helt selvtilliten. Ved neste fødsel jeg var delaktig i, holdt jeg meg mer i bakgrunnen. (Anna)

Studenten som hadde rollen som veileder, hadde blikkontakt med Anna under fortellingen og bekreftet med nikk og iblant smil. Innimellom noterte hun. Etter fortellingen stilte veilederen ulike spørsmål som Anna reflekterte rundt. Anna kom ved hjelp av spørsmålene frem til at hun hadde en forventning om at hvis hun motiverte kvinnen, kom kvinnen til å mestre riene godt, og det ville bli normal fremgang i fødselen. Hun tok dermed regien over fødselen, og kvinnen fulgte Annas råd.

Da teamet diskuterte, beveget de seg først inn i temaet kommunikasjon og samarbeid, før de landet på at Anna ikke kunne vite noe sikkert om det fremtidige fødselsforløpet, uavhengig av hva hun sa eller gjorde. Teamet hadde mange betraktninger rundt hvordan man kan arbeide med fødekvinnen og bidra til trygghet.

Ordet gikk så tilbake til studenten som var veileder, og Anna. Etter å ha hørt på samtalen i teamet ble Anna opptatt av hvordan hun ville ha tenkt hvis fødselen hadde gått fremover slik som hun forventet. Ville hun da ha tatt det for gitt at det skyldtes hennes egen innsats i form av motivasjon og hjelp? Her innså hun at fødeprosesser som i utgangspunktet er normale, kan forløpe i komplisert retning selv om det gis god fødselshjelp. Den jordmorhjelpen Anna skulle gi kvinner fremover, rommet dermed noen utfordringer hun ikke tidligere hadde sett. 
Teamet kom i sin andre runde frem til at det var mye man ikke kunne forutse, og at å svare på spørsmål og ordlegge seg uten å gi løfter om fødselsprogresjon var en viktig ferdighet å utvikle. I dialogen kom teamet frem til at tidligere erfaringer kunne påvirke hvordan jordmoren ville møte en situasjon.

Det har jeg ikke tenkt på før! sa Anna. Det handlet nok litt om kommunikasjon, men saken var at jeg møtte meg selv i døra. Det var mine egne private erfaringer med epidural jeg tok med meg i vurderingen av situasjonen. Jeg har selv dårlige erfaringer med det, og det ville jeg ikke at denne fødekvinnen skulle få. Men jeg kan ikke la mine private erfaringer styre mine faglige vurderinger. I nye situasjoner med andre fødekvinner må jeg være bevisst på dette. Det som er rett for meg, er ikke nødvendigvis rett for andre kvinner, og nå skal jeg bruke min faglige kunnskap til å vurdere situasjonene. (Anna)

Etter dette åpnet mentor for refleksjon rundt rollene - hvordan det var å ha rollen som veileder, veisøker (Anna) og som aktør i teamet. Rollen som veileder ble beskrevet som spesielt utfordrende. Det var krevende å holde seg fra å mene noe om situasjonen og i stedet fokusere på spørsmål som kunne få Anna til å fortelle mer og utfordre sin forstålse. For veilederen ble bevisstheten om åpne spørsmål og lyttende posisjon tydelig. Studenten Anna uttrykte at det var godt å få fortelle om denne situasjonen, og viktig å høre at de andre studentene kunne kjenne seg igjen i denne erfaringen. Den kunnskapen som veiledningen hadde bidratt til, ville hun bruke til å forbedre sin praksis $\mathrm{i}$ fremtidige situasjoner.

En viktig del av RT er samtalen om det jordmorfaglige innholdet i veiledningen, og i etterkant av Annas fortelling ble flere jordmorfaglige tema belyst. Det handlet om kunsten å arbeide for en normal og ukomplisert fødselsprosess, men samtidig ha handlingsberedskap for avvik og komplikasjoner som kan oppstå underveis i prosessen. Jordmoren må utvikle en handlingsberedskap der hun må vite hva hun ser, og forstå hva dette betyr, og ha praktisk evne til å møte og handle i situasjonen. Dette krever profesjonell kompetanse. Flere aspekter ved profesjonell jordmorkompetanse ble belyst, der også maktbegrepet ble diskutert. Mentoren bidro her med forslag til litteratur som kunne gi dypere forståelse, både med hensyn til temaet epidural og til mer overordnet teori om møtet med kvinner i lignende situasjoner. 


\section{Teoretiske perspektiver}

Psykiater Tom Andersen utviklet metoden RT først og fremst som en terapeutisk metode, men Andersen (2011) fremmet også metodens anvendbarhet ved veiledning og teamarbeid. Metoden fokuserer på aktiv deltagelse, samarbeid og undersøkelse av egen praksis, der den profesjonelle yrkesutøveren gjennom samtale kan oppnå profesjonell utvikling. Nettopp strukturen $\mathrm{i}$ samtalen kan gi studentene mulighet til å bryte vante tankemåter og understøtte refleksjonsprosesser (Andersen, 2010).

Rollen som veileder er en krevende posisjon i RT. Rollen kan gi studenten som er veileder, viktig erfaring som er overførbar til jordmorfaglig praksis. Lytteposisjonen karakteriseres av å lytte til innholdet eller saken (Skjervheim, 1996), for videre å bygge opp et bilde av det veilederen forstår som ordenes mening. Spence (1984) fremhever betydningen av å komme «bak ordene», slik at veilederen kan forstå og bruke ordene til den som får veiledning. Ved å bruke ordene til den som får veiledning i nye spørsmål, vil veilederen gjennom dialogen kunne nærme seg en større innsikt i medstudentens fortelling og hjelpe den som får veiledning, til å fange opp viktige perspektiver i egen sak. Veilederen oppfordres til å vise ydmykhet og respekt for den som får veiledning, ved å stille spørsmål i stedet for å uttrykke egne meninger og oppfatninger om saken. Spørsmål gir mulighet for selv å velge det man vil svare på. Et annet aspekt ved veilederens rolle er å ikke passere sentrale punkter i samtalen for selv å finne løsning på disse, men å stoppe opp og formulere spørsmål som kan hjelpe den som făr veiledning, til å finne svarene selv (Andersen, 2011). Studentene i teamet skal i en anerkjennende samtale om det de har hørt, hva som berørte dem, hva det handler om, og hvordan de forstår saken (Skjervheim, 1996), lære å uttrykke forståelse uten at de går inn på å forklare saken (Andersen, 2010).

RT er en konstruktivistisk veiledningsmetode der kunnskap utvikles gjennom dialog og relasjon mellom mennesker. I dialogen får ordene mening i lys av nye ord og perspektiver. I samtalen søkes det etter ord som kan uttrykke det man mener, noe som vil klarne tankene og forstålsen (Andersen, 2011). I en pedagogisk kontekst er det den profesjonelle og faglige utviklingen som er sentrum for samtalen. Man søker å knytte personlige holdninger til profesjonell jordmorfaglig utvikling og ikke til private temaer. Inspirert av John Dewey (2009) forstås læringsbegrepet som refleksjon over praksis for å oppnå ny innsikt og forståelse, og på bakgrunn av den nye forståelsen foretas nye 
handlinger som ikke kun forandrer praksis, men også den som tenker og handler. Kunnskapsutvikling kan forstås i lys av sosiokulturell læringsteori, der kunnskap blir konstruert gjennom samhandling mer enn gjennom individuelle prosesser (Dysthe, 2001). Dialog og interaksjon utgjør grunnleggende faktorer for læring. Den lærende er alltid en del av en kontekst, og utvikling av kunnskap må forstås i relasjon til denne sammenhengen. I et sosiokulturelt læringsperspektiv er det viktig å skape et læringsmiljø der studenten blir anerkjent og får bidra med kunnskap i fellesskapet. Studentene kan i tråd med Lev Vygotskijs (1978, s. 87) begrep «Zone of Proximal Development» (ZPD) gis mulighet til å utfordre og mobilisere egen læringskapasitet i dia$\log$ og samarbeid med andre. I RT innebærer dialogen å trene på å lytte for å kunne ta inn over seg den andres følelser og verdier. På denne måten omfatter dialogen et etisk ansvar som gir dialogen dybde og moralsk forpliktelse (Bakhtin, 1998).

RT representerer en dialogbasert og studentaktiv læringsmetode som fremmer læring i interaksjon med andre. Deltagerne lærer noe nytt og utvider sin eksisterende forståelse i dette fellesskapet (Gergen \& Gergen, 2005; Dysthe, 2001). Når studentene forteller, bygges narrativet rundt et poeng eller en erfaring som er viktig for studenten. Fortellingen endres og bearbeides gjennom dialogen og prosessene i RT og kan for studentene settes inn i en ny faglig sammenheng, et nytt faglig narrativ (Polkinghorne, 1995). En narrativ tilnærming til læring kan ifølge Geert Kelchtermans (1993) kjennetegnes som 1) konstruktivistisk fordi deltagerne konstruerer sine yrkeserfaringer i en fortelling. Tilnærmingen er 2) kontekstuell fordi fortellingen er hentet fra en kontekst og utvikles i en ny kontekst, som i denne sammenheng utgjør samarbeidet i RT. Den nye forståelsen av fortellingen konstrueres 3) dialogisk mellom dem som deltar i RT. Den narrative tilnærmingen er også 4) dynamisk fordi den bygger på tidligere læring og erfaring, den nåværende situasjonen og de fremtidige perspektivene som fremstår gjennom lærings- og refleksjonsprosessen. I denne læringsprosessen vil læring og kunnskap kunne utvikles (Kelchtermans, 1993).

\section{Utvikling av datamaterialet}

Studentene beskrev sin forståelse og læring med egne ord i refleksjonsloggene, og disse ble meddelt skriftlig til oss som lærere og forfattere. Refleksjonsloggene 
er ifølge Paul Ricoeur (1977) signifikante data som kan bidra til kunnskap gjennom transkripsjon, analyse og tolkning. Datamaterialet kan få en mer omfattende mening når den gjøres til gjenstand for analyse, tolkning og diskusjon i et nytt narrativ (Ricoeur, 1977), som i denne sammenheng utgjør dette kapittelet.

Gruppen som deltok i studien, utgjorde til sammen 35 studenter, alle kvinner i alderen 25 til 46 år, fordelt på tre årskull (2018, 2019 og 2020). Datamaterialet består av studentenes refleksjonslogger. Før transkribering utgjorde dette 138 håndskrevne logger, som til sammen ble til 28 A4-sider (Microsoft Word) transkribert materiale.

\section{Etiske implikasjoner}

Datamaterialet som er utviklet, består ikke av personopplysninger som kan spores tilbake til deltagerne i studien, og dette er ifølge Norsk senter for forskningsdata (NSD) ikke meldepliktig. Refleksjonsloggene som utgjør datamaterialet, ble skrevet for hånd på et eget skjema av den enkelte student og levert anonymt til læreren. Studentene er tidligere utdannede sykepleiere og er innforstått med helsepersonells ansvar og taushetsplikt. I tillegg er etiske retningslinjer for jordmødre utarbeidet av International Confederation of Midwives (ICM 2014) diskutert med studentene.

\section{Analyse}

Forskningsspørsmålet, hvordan kan veiledningsmetoden RT bidra til jordmorstudentenes læring og kunnskapsutvikling, Annas fortelling samt studiens teoretiske perspektiv har gitt retning for analysen av datamaterialet. Analysen av datamaterialet har inngått som en interaktiv og dialogbasert prosess gjennom hele prosjektperioden (2018-2020), og denne prosessen har gitt forfatterne mulighet til å reflektere over studentenes læring. I etterkant av prosjektperioden har datamaterialet gjennomgått en tematisk analyse inspirert av Lindseth \& Norberg (2004).

Analyseprosessen startet med naiv lesning og gjennomgang av datamaterialet. Datamaterialet ble delt opp i meningsenheter og utviklet videre til temaer og sub-temaer, og videre kondensert til tre hovedtemaer. Datamaterialet ble 
igjen lest i sin helhet, og utdrag fra datamaterialet som illustrerte hovedtemaene, ble valgt ut. I analyseprosessen ble det mulig å fremlegge temaer med tanke på å utvikle aktuell kunnskap om RT som lærings- og veiledningsmetode i jordmorutdanningen.

Analysen av studentenes refleksjonslogger har gitt forfatterne innsikt i noen av studentenes erfaringer med å utvikle jordmorfaglig kunnskap og kompetanse gjennom metoden RT. Studentene har fått erfaring med de ulike rollene i RT. De har oppdaget betydningen av kommunikasjon i jordmorfaget og utviklet bevissthet og selvinnsikt. Gjennom medstudentenes fortellinger har studentene fått innsikt i et mangfold av situasjoner fra klinisk praksis, som har gitt dem mulighet til refleksjon og læring.

\section{Resultat}

I analysen av datamaterialet fremstår følgende hovedtema som resultat:

- Betydningen av å fortelle frem sin fortelling.

- Erfaring med veilederrollen i jordmoryrket.

- Innsikt i gjennomføring av profesjonelle samtaler.

\section{Betydningen av å fortelle frem sin fortelling}

Studentene velger en selvopplevd situasjon fra egen praksis som jordmorstudent. Situasjonen presenteres som en fortelling med studenten selv i fokus, slik Annas fortelling illustrerer. Fortellingene inneholder utfordringer de har tenkt på i ettertid, og som vanligvis ikke fanges opp i annen undervisning og veiledning i jordmorutdanningen. Studentene beskriver sine erfaringer med å være den som får veiledning, på flere måter.

Jeg ser nå en stor fordel med en slik gruppe som RT fordi jeg så mye annet i situasjonen enn jeg hadde tenkt. Jeg forsto at det er andre måter å tenke på, og hvordan situasjonene eventuelt kan løses. (Student, 2019) 
Jeg synes det var bra å få reflektere høyt om en hendelse som jeg alene har tenkt på i lang tid. Det var nærmest befriende å få veiledning om det, og sette ord og nye ord på det man har opplevd og tenkt på. (Student, 2020)

Det kan ligge mye bak en kvinnes vanskelige adferd. Det er viktig å tenke over dette. Hvordan kan jeg i samarbeid med kvinnen forstå mer av hennes situasjon? Det kan ligge noe bak fasaden som er viktig å få innsikt i for å kunne hjelpe kvinnen. (Student, 2018).

Sitatene illustrerer betydningen av å få fortelle om egne erfaringer fra praksis. Det å fortelle er i seg selv en viktig erfaring for jordmorstudenten, og det er en kunnskap som kan overføres til situasjoner i jordmorpraksis der studentene skal få innsikt $\mathrm{i}$ kvinnens livsfortelling.

\section{Erfaring med veilederrollen i jordmoryrket}

Studentene beskriver veilederposisjonen i RT som en komplisert posisjon der de oppdaget betydningen av å lytte og fange opp viktige elementer i samtalen.

Jeg må våge å lytte og være stille, og ikke bryte inn. Jeg må øve på å stille åpne spørsmål som hjelper den som får veiledning til å tenke og se noe nytt i egen situasjon. (Student, 2018)

Studentene beskriver at de blir bevisst egen kommunikasjon og det de selv sier i situasjonen, og at denne oppdagelsen har betydning for all kommunikasjon i jordmorvirksomheten. Erfaringene har betydning for kommunikasjonen med kvinnen og hennes partner, med medstudenter, veiledere og fremtidige kollegaer. Kunnskapen om egen kommunikasjon kan overføres og transformeres til nye situasjoner.

I akutte situasjoner er det viktig å være trygg på egen handlingskompetanse og bevisst på jordmorens ansvar for kommunikasjon og ledelse, der kommunikasjon må være tydelig og klar. (Student, 2020) 


\section{Innsikt $i$ gjennomforing av profesjonelle samtaler}

Studentene erfarer som deltagere i teamet at de ser flere perspektiver med fortellingen, og at de kjenner seg igjen i situasjonen.

Jeg må bli mer bevisst mine holdninger og hvilken jordmor jeg ønsker å bli. (Student, 2018)

At det er nyttig å høre hva de andre tenker om situasjonen og at vi sammen kan komme fram til og undre oss over nye synspunkter. Viktig å være en god lytter. Ofte ønsker man å prate mer enn man lytter. Veiledning hjelper en til å bli en bedre lytter. (Student, 2018)

Jo mer engasjerende et tema er, desto vanskeligere er det å holde en diskusjon fokusert mot fortellingen til veisøker. Studentene erfarer at de raskt mister fokus og tar inn egne erfaringer i samtalen i teamet. Men de opplever også at de klarer å rette samtalen mot saken det samtales om, noe som gir mening for studentene.

Jeg opplever at det kan komme svært gode diskusjoner i teamet som vi antagelig ikke ville hatt om ikke RT hadde gitt oss denne muligheten. Man kan selv styre det man ønsker å høre mer om. Man kan hjelpe hverandre til å se saken fra flere sider. Man kan i samtalen åpne for ny input. (Student, 2020)

Aktiv lytting og åpne spørsmål gjør at vedkommende klarer å hente frem sin egen refleksjon og følelser. Veileder forteller ikke sin egen mening, slik at den som blir veiledet eier sin egen opplevelse. (Student, 2020)

Studentene forteller om situasjoner fra praksisperioden der de er redde, sinte, glade, fortvilte, føler at de gjør en god jobb, og føler seg utilstrekkelige, samt situasjoner der de har kunnet møte utfordringene. De kjenner seg igjen i den andres fortelling og mangfoldet av egne følelser som de må forstå.

Det er greit å være redd, men det også greit å fortelle om det. Hva kan man gjøre for å bli trygg i situasjonen? Det å være trygg betyr å 
være bevisst når man føler seg utrygg. Det innebærer at jeg er ærlig mot meg selv og ser mine begrensninger. (Student, 2018)

Studentene oppdager at de selv har et medansvar for hvordan en veiledningssituasjon i praksis kan bli god eller vanskelig og at de selv har ansvar for egen læring. Det kan være vanskelig å si ifra og tørre å stå opp for seg selv.

Jeg må trene på å lage gode rutiner sammen med veileder, og bidra til god kommunikasjon med jordmor som veileder meg. Jeg har oppdaget at det er viktig med refleksjon over hendelser i praksis. Da kan man se hvordan ting kan gjøres annerledes. Og man kan lære av hendelsen. (Student, 2020)

RT kan gi studentene mulighet til å forstå betydningen av refleksjon for å fremme egen læring. De ser seg selv og sin praksis utenfra og på nye måter. Sammenhengen mellom personlig og profesjonell kompetanse blir tydeligere for dem, og de opparbeider seg bevissthet om hva som påvirker deres fremtidige praksis.

\section{Studentens utvikling av et profesjonelt selvbilde - et narrativ som jordmor}

I studien som kapittelet omhandler, har vi utviklet kunnskap om hvordan RT som en lærings- og veiledningsmetode kan bidra til jordmorstudentenes læring og utvikling av profesjonell jordmorfaglig kompetanse. Studentene kan gjennom RT få hjelp til å forstå seg selv i en ny yrkesrolle, og de utvikler bevissthet om hva denne rollen kan innebære. Andersen (2011) fremmer betydningen av at erfaring med strukturen og rollene i RT kan bidra til læring. Studentene erfarer at det å fortelle om en hendelse er en meningsfull måte å lære på. Studenten Anna oppdager at hun baserer sin informasjon til kvinnen på egne private opplevelser med bedøvelsen epidural. Hun gjør sine antakelser og verdier synlige for alle i teamet, inkludert seg selv. I veiledningsprosessen oppdager Anna at hun må basere sin kommunikasjon med kvinnen på profesjonelle og faglige begrunnelser som samsvarer med jordmoryrkets kunnskap og etikk. Når studenten forteller sitt narrativ (Kelchtermans, 
1993), kan hun skape kunnskap og utvikle sin forståelse for jordmorfaget og seg selv som yrkesutøver. Studenten vil dermed erfare at hennes narrativ kan utvikles og gi ny innsikt innenfor konteksten og rammene av RT som en lærings- og veiledningsmetode. Nielsen et al. (2019) fremhever i sin studie at studentene gjennom workshops som var inspirert av metoden RT, styrket egen læring og bevissthet om seg selv som profesjonell yrkesutøver.

Studentene beskriver rollen som veileder som en krevende posisjon i RT. I denne rollen fikk studentene erfaring og mulighet til å utvikle bevissthet og innsikt i egen kommunikasjon. Lynn Nicholls \& Christine Webb (2006) og Sara Borrelli (2014) fant i sine studier at bevissthet om profesjonell kommunikasjon er en sentral og viktig jordmorkompetanse. Studentene oppdaget at erfaringer fra veilederrollen var overførbare til flere situasjoner som krever kunnskap om profesjonell kommunikasjon. I konsultasjoner med kvinnen må jordmoren ha kunnskap om hvordan hun kan legge til rette for en anerkjennende og gjensidig dialog (Skjervheim, 1996). I likhet med veilederens rolle i RT vil jordmorens rolle i samtaler med kvinnen innebære at hun kan stille spørsmål som hjelper kvinnen til å oppdage og forstå sine muligheter. Det innebærer blant annet å kunne lytte og stille spørsmål til det kvinnen formidler, slik at kvinnen selv kan velge ut den informasjonen hun vil gi om seg selv. Jordmoren må også ha bevissthet om at hun ikke kan passere sentrale punkter i samtalen med kvinnen, for selv å finne en løsning på disse. Hun bør kunne gi kvinnen tid og rom slik at hun kan finner løsninger for seg selv, men være støttet av jordmorens profesjonelle kunnskap.

I alle posisjonene i RT utfordres studentene til å arbeide aktivt og systematisk med egne kommunikasjonsferdigheter. Lytteposisjonen i veilederrollen innebærer, slik Skjervheim (1996) beskriver den, å lytte aktivt til innholdet i det veisøker forteller. Veileder kan ved å lytte danne seg et bilde av meningen med ordene og innholdet i den andres fortelling (Spence, 1984). Studentene i studien erfarte at å stille spørsmål som åpnet for dialog, var en utfordrende øvelse som de måtte trene på. Andersen (2011) påpeker at spørsmål kan åpne opp for samtale, fordi spørsmål gir valgmuligheter for den som skal svare. Anna fikk gjennom spørsmålene veilederen stilte, og ved å lytte til samtalen i teamet mulighet til å fordype sin innsikt i egen fortelling. Alt som fremstår i dialogen, har betydning for den som får veiledning, slik at hun kan utvikle sin evne til refleksjon, og dermed utvide sin forståelse (Schilling, 2003). 
Studentene erfarte at det var mulig å sette ord på følelser som kan være vanskelige å formidle. Annas faglige usikkerhet kom tydelig frem i veiledningsprosessen i RT. I dialogen og samarbeidet med medstudentene fikk hun mulighet til å oppdage flere viktige perspektiver ved sin egen fortelling, som ble meningsfull for henne. Fortellingen kan når den bearbeides på en respektfull måte, påvirke og forme studenten som menneske og støtte hennes personlige og profesjonelle utvikling som jordmor. Andersen (2011) påpeker at det er viktig å være oppmerksom på at usikkerhet og overbevisning kan komme til uttrykk i dialogen i RT, og kan utgjøre gode kilder til kunnskap.

Bass et al. (2017) og Embo et al. (2015) beskriver i sine studier betydningen av systematisk refleksjon som læringsverktøy i jordmorutdanningen. Et viktig aspekt ved å integrere systematisk refleksjon i jordmorutdanningen er ifølge Collington og Hunt (2009) at studentene vil fortsette å være åpne for refleksjon og integrere prinsipper for livslang læring i sin yrkesutøvelse, noe også studentene i denne studien viste en begynnende forståelse for. Den typen refleksjon som etterstrebes i RT, har som mål å gi jordmorstudentene et grunnlag for livslang læring. Wackerhausen (2015, s. 99) hevder at «erfaring uten refleksjon er blind, og at refleksjon uten erfaring er tom». For å unngå at erfaring sementeres som statisk og ureflektert praksis i et fag i stadig endring, er kompetanse i kritisk refleksjon avgjørende og viktig. Systematisk avansert refleksjon som læringsaktivitet kjennetegnes i RT av at det utfordrer veisøkers verdier, kunnskap og antakelser som bakgrunn for det narrativet som presenteres. Når studenten skaper og presenterer sitt narrativ og gjør det til gjenstand for undersøkelse, erkjenner hun samtidig sin uvitenhet i saken, slik Anna forteller: "Jeg visste ikke hva jeg skulle si lenger.» Denne erkjennelsen er en forutsetning for å kunne se seg selv utenfra og granske sin forståelse. Det kreves altså både førstehåndserfaring, strukturert dialog og mot for å iscenesette avansert refleksjon i denne sammenhengen. For å forstå hva hun kan forbedre ved egen praksis, må jordmorstudenten først forstå hva hun er blind for ved den praksisen hun hittil har utøvd. Dette er anstrengende arbeid og krever at studenten reflekterer dypere enn hun vanligvis gjør, i sin kliniske praksis.

Når teamet inviteres inn i dialogen i RT, bes de om å sette søkelys på hva samtalen handler om, og hvordan de forstår saken i dialogen. Studentene bes tenke over om det er noe de fornemmer i samtalen, eller noe som berører dem i fortellingen til medstudenten. Ved å sette ord på slike fornemmelser kan det skapes mening. Teamet kan også få et konkret oppdrag fra veisøker, 
der veisøker har et klart formulert spørsmål eller tema hun ønsker belyst. I samtalen i teamet kan studentene lære å uttrykke forståelse uten at de går inn på å forklare saken (Andersen, 2010). Det er veisøkers forståelse som er viktig å utfordre, ikke situasjonen i fortellingen (Skjevheim, 1996). I likhet med i profesjonell jordmorvirksomhet skal veisøker gis tid og rom til å finne løsningene selv. Kompetansen som utvikles i læringsprosessen (RT), er dermed direkte overførbar til jordmorfaglig handling og virksomhet.

Med hensyn til læring vil RT representere en dialogbasert og studentaktiv læringsmetode som fremmer læring i interaksjon med medstudenter der deltagerne lærer noe nytt og utvider sin eksisterende forståelse i dette fellesskapet (Gergen \& Gergen, 2005; Dysthe, 2001). Når studentene forteller sin historie i RT, slik fortellingen til Anna er et eksempel på, forteller hun frem sitt narrativ rundt et poeng (Polkinghorne, 1995) som er viktig for henne, og som hun setter inn i en jordmorfaglig sammenheng. Studentenes fortellinger er viktige fortellinger som gjennom en narrativ tilnærming til læring kjennetegnes som konstruktivistisk fordi deltagerne konstruerer sine yrkeserfaringer og identitet i sitt narrativ (Kelchtermans, 1993). Fortellingene beskriver jordmorstudentenes kliniske praksis og blir utviklet i en ny kontekst som i denne sammenheng utgjør dialogen og samarbeidet i RT. Den nye innsikten i for eksempel Annas narrativ konstrueres mellom studentene som deltar i RT. Den narrative tilnærmingen er dynamisk fordi den bygger på studentens tidligere læring og erfaring, den nåværende situasjonen og de fremtidige perspektivene som fremstår gjennom lærings- og refleksjonsprosessen i RT. Studentene får mulighet til å utvikle sin forståelse av seg selv som profesjonell jordmor gjennom denne prosessen.

Studentene fikk gjennom RT erfaring med å reflektere over egne praksiserfaringer, noe som ifølge Fullerton et al. (2013) og Carter et al. (2017) kan fremme studentenes innsikt og forståelse av egen læringsprosess. Studentene i denne studien fikk erfaring med kritisk refleksjon og oppdaget hvordan refleksjon har betydning for klinisk praksis. Annas fortelling illustrerer dette poenget når hun oppdaget og ble bevisst på hvordan hennes fortelling ble til kunnskap i samarbeid med studentene. Denne bevisstheten er en essensiell del av kompetansen hos en reflektert praktiker. Gilkison et al. (2016) påpeker betydningen av at studentene forstår det unike møtet med den enkelte kvinne, og at de kan tilpasse den jordmorfaglige vurderingen og omsorgen til henne. 
Narrativet gir et bilde av en student som prøver å finne ut av hva det innebærer å utvikle seg til en profesjonell og god jordmor, og oppdager nye sider ved egen utvikling. I likhet med Anna ønsket også medstudentene å utvikle seg til gode jordmødre. Jordmorrollen er ifølge Sheena Byrom \& Sue Downe (2010) relatert både til personlig, generell og emosjonell kompetanse. I Borrellis (2014) studie ønsker kvinner at jordmoren innehar teoretisk kunnskap, profesjonell kompetanse, personlige kvaliteter, kommunikasjonsferdigheter og moralske og etiske verdier. Jordmoren må gi profesjonell støtte, gi kvinnen valgmuligheter, støtte kvinnens behov for kontroll og gi henne tilstrekkelig og riktig informasjon. RT tilbyr studentene et verktøy for å oppnå denne kompetansen.

\section{Avslutning}

Studentene vil i løpet av jordmorstudiet oppdage yrkets kompleksitet og hvilke krav og forventninger som stilles til profesjonell yrkesutøvelse. RT er en strukturert lærings- og veiledningsmetode som gjennom dialogiske og narrative prosesser gir studentene mulighet til å tolke og forstå fortellinger fra praksis. Studentene får gjennom dialog og refleksjon mulighet til å utvikle et profesjonelt selvbilde gjennom narrativ, noe som innebærer å se flere perspektiver ved situasjonen, oppdage sammenhengen mellom teori og praksis og bli bevisst etiske og moralske aspekter i jordmoryrket. RT er en læringsarena der studentene kan sette søkelys på sin egen personlige og faglige utvikling gjennom refleksjon over selvopplevde praksiserfaringer. Dette er kunnskap studentene ikke kan tilegne seg via pensumlitteratur eller konstruerte caser. Det er avgjørende viktig at det finnes en arena for denne typen kompetanseutvikling i alle studier som forbereder studenter til yrker som inkluderer menneskemøter. 


\section{Referanser}

Andersen, T. (2010). Reflekterende processer. Samtaler og samtaler om samtalerne. (3. utg., 6. oppl.). København: Dansk psykologisk forlag

Andersen, T. (2011). Et samarbeid, av noen kalt veiledning. I M. H. Rønnestad \& S. Reichelt (red.), Veiledning i psykoterapeutisk arbeid, s. 89-95. Oslo:

Universitetsforlaget.

Bakhtin, M. M. (1998). Spørsmålet om talegenrane [The Problem of Speech Genres]. Oversettelse og etterord av R.T. Slaattelid. Bergen: Ariadne Forlag.

Bass, J., Fenwick, J. \& Sidebotham, M. (2017). Development of a model of holistic reflection to facilitate transformative learning in student midwives. Women and Birth: Journal of the Australian College of Midwives, 30(3), s. 227-235.

DOI: https://doi.org/10.1016/j.wombi.2017.02.010

Borrelli, S. E. (2014). What is a good midwife? Insights from the literature. Midwifery, 30(1), s. 3-10. DOI: https://doi.org/10.1016/j.midw.2013.06.019

Byrom, S. \& Downe, S. (2010). 'She sort of shines': midwives' accounts of 'good' midwifery and 'good' leadership. Midwifery, 26(1), s. 126-137.

DOI: https://doi.org/10.1016/j.midw.2008.01.011

Carter, A., Creedy, D. \& Sidebotham, M. (2017). Critical thinking skills in midwifery practice: Development of a self-assessment tool for students. Midwifery, 50, s. 184-192. DOI: https://doi.org/10.1016/j.midw.2017.04.010

Collington, V. \& Hunt, S. C. (2009). Reflection in midwifery education and practice: An exploratory analysis. Evidence Based Midwifery, 4(3), s. 76-82. Gale Academic OneFile, https://link.gale.com/apps/doc/A167030957/AONE?u=anon fc4c9760\&sid=bookmark-AONE\&xid=f11f100b. Hentet 09.11.2021.

Dewey, J. (2009). Hvordan vi tenker. Oversatt av J. Wrang. Aarhus: Forlaget Klim.

Dysthe, O. (2001). Sosiokulturelle teoriperspektiv på kunnskap og læring. I Dysthe, O (red) Dialog, samspel og laring 2001. Oslo: Abstrakt forlag.

Embo, M. \& Valcke M. (2015). Continuing midwifery education beyond graduation: Student midwives' awareness of continuous professional development. Nurse education in practice, 24, s. 118-122.

DOI: https://doi.org/10.1016/j.nepr.2015.08.013

Fullerton, J. T., Thompson, J. B. \& Johnson, P. (2013). Competency-based education: The essential basis of pre-service education for the professional midwifery workforce. Midwifery, 29(10), s. 1129-1136.

DOI: https://doi.org/10.1016/j.midw.2013.07.006 
Gergen, K. J. \& Gergen, M. (2005). Social konstruktion - Ind i samtalen. København: Dansk psykologisk forlag.

Gilkison, A., Giddings, L. \& Smythe, L. (2016). Real life narratives enhance learning about the 'art and science' of midwifery practice. Advances in Health Sciences Education, 21(1), s. 19-32. DOI: https://doi.org/10.1007/s10459-015-9607-z

Kelchtermans, G. (1993). Getting the story, understanding the lives: From career stories to teachers' professional development. Teaching and Teacher Education, 9(5-6), s. 443-456. DOI: https://doi.org/10.1016/0742-051X(93)90029-G

Lincoln, Y. S. \& Guba, E. G. (1985). Naturalistic Inquiry. Newbury Park, CA: Sage.

Lindseth, A. \& Nordberg, A. (2004). A Phenomenological Hermeneutical Method for Researching Lived Experience. Scandinavian Journal of Caring Sciences, 18(2), s. 145-153. DOI: https://doi.org/10.1111/j.1471-6712.2004.00258.x

Macdonald, S. (2017). The midwife as a lifelong learner. I S. Macdonald \& G. Johnsen (red.), Mayes Midwifery (15. utg.). Edinburgh \& New York: Elsevier.

Nakielski, K. P. (2005). The reflective practitioner. I M. D. Raynor, J. E. Marshall \& A. Sullivan (red.), Decision making in midwifery practice s. 143-154. New York, NY: Churchill Livingstone.

Nicholls, L. \& Webb, C. (2006). What makes a good midwife? An integrative review of methodologically-diverse research. Journal of Advanced Nursing, 56(4), s. 414429. DOI: https://doi.org/10.1111/j.1365-2648.2006.04026.x

Nielsen, L. S., Munch, P. \& Nielsen, A. (2019). Praksisnær forskning dannelse af professionel identitet gennem refleksiv praksislæring. Tidsskrift for professionsstudier, 15(29), s. 62-73. https://tidsskrift.dk/tipro/article/ view/116405/164517 Hentet 22.11.2021

Norsk senter for forskningsdata. https://nsd.no/personvernombud/meld_prosjekt/ meldeskjema Hentet 09.11.2021

Polkinghorne, D. E. (1995). Narrative configuration in qualitative analysis. International Journal of Qualitative Studies in Education, 8(1), s. 5-23. DOI: https://doi.org/10.1080/0951839950080103

Ricoeur, P. (1977) “The Question of Proof in Freud's Psychoanalytic Writings." Journal of the American Psychoanalytic Association 25 (4), s. 835-871. DOI: https://doi.org/10.1177/000306517702500404

Schilling, B. (2003) Systemisk supervisjonsmetodik. Et sprogspil for professionelle, der avender supervision. København Dansk Psykologisk Forlag.

Schön, D. (1987). Educating the Reflective Practitioner. Toward a New Design for Teaching and Learning in the Professions. San Francisco, CA: Jossey-Bass. 
Spence, P. (1984). Narrative truth and historical truth. Meaning and interpretation in psychoanalysis. New York: W.W. Norton \& Company.

Sweet, L., Bass, J., Sidebotham, M., Fenwick, J. \& Graham, K. (2019). Developing reflective capacities in midwifery students: Enhancing learning through reflective writing. Women and Birth, 32(2), s. 119-126. DOI: https://doi.org/10.1016/j. wombi.2018.06.004

Skjervheim, H. (1996). Deltakar og tilskodar og andre essays. Oslo: Aschehoug forlag. International Confederation of Midwives [ICM] (2013). Global Standards for Midwifery Education. https://www.internationalmidwives.org/assets/files/generalfiles/2021/09/global-standards-for-midwifery-education_2021_en.pdf Hentet 22.11.2021

International Confederation of Midwives [ICM] (2014). International Code of Ethics for Midwives. https://www.internationalmidwives.org/assets/files/generalfiles/2019/10/eng-international-code-of-ethics-for-midwives.pdf Hentet 09.11.2021

UiT Norges arktiske universitet. Det helsevitenskapelige fakultet. Institutt for helse og omsorgsfag. Studieplan for master i jordmorfag (2019)

Vygotskij, L. S. (1978). Mind in Society. I M. Cole, V. John-Steiner, S. Schribner, E. Souberman (red.) Mind in Society: The development of higher psychological processes. Cambridge; Mass.: Harvard University Press.

Wackerhausen, S. (2009). Collaboration, professional identity and reflection across boundaries. Journal of Interprofessional Care, 23(5), s. 455-473.

DOI: https://doi.org/10.1080/13561820902921720

Wackerhausen, S. (2015). Erfaringsrom, handlingsbåren kunnskap og refleksjon. I J. McGuirk \& J. S. Methi (red.), Praktisk kunnskap som profesjonsforskning s. 81-100. Bergen: Fagbokforlaget.

Aadland, E. (2018). Etikk i profesjonell praksis. Det Norske samlaget. 